\title{
Effect of Post Harvest Treatments on Storage Quality of Ber (Ziziphus mauritiana Lamk.) under Cold Storage Condition cv. Gola
}

\author{
N. A. Patel*, B. H. Panchal and M. B. Rathod \\ Department of Horticulture, B. A. College of Agriculture, Anand Agricultural University, \\ Gujarat-383317, India \\ *Corresponding author
}

Keywords

$\mathrm{CaCl}_{2}, \mathrm{GA}_{3}$, wax, cold storage, shelf life, ber

Article Info

Accepted: 12 May 2021 Available Online: 10 June 2021
An experiment was conducted to study the effect of post-harvest treatments on storage quality and shelf life of ber (Ziziphus mauritiana Lamk.) under cold storage condition cv. Gola. The experiment was conducted during the Rabi2020 at Horticultural Research Farm and P. G. Laboratory, Department of Horticulture, B. A. College of Agriculture, Anand Agricultural University, Anand, Gujarat. Freshly harvested at physiological maturity of uniform size selected fruits were subject to post harvest treatments viz., $\mathrm{GA}_{3}(20,40$ and 60 ppm), $\mathrm{CaCl}_{2}(0.5,1.0$ and $2.0 \%)$ along with wax coating $(6 \%)$ and without wax coating. Periodic observations at $5^{\text {th }}, 10^{\text {th }}, 15^{\text {th }}$ and $20^{\text {th }}$ day of storage were taken for evaluation of storage quality. The study results revealed that fruits treated with $\mathrm{CaCl}_{2} 2.0 \%$ when coated with wax $(6 \%)$ resulted in prolonging shelf life upto15 days with minimizing physiological loss in weight, spoilage, acidity and increased marketable fruits, firmness with maintaining higher level of TSS, ascorbic acid, total sugar, reducing sugar and non reducing sugar as compared to the control (water spray and without wax).

\section{Introduction}

Ber (Ziziphus mauritiana Lamk.) is one of the most ancient and common fruit of India and it is cultivated practically all over the country. Being a hardy fruit, it can be grown even on inferior and marginal lands. Ber is indigenous to an area stretching from India to China and Malaysia. In view of good returns from ber, its cultivation is becoming increasingly popular in Gujarat and other states of North India, especially in Punjab, Haryana, and Rajasthan. It is nutritive and delicious. Generally, gibberellic acid is known for its anti-senescing properties which results in delaying ripening of fruits. Fruits generally have a considerable amount of Calcium in their tissues. The $\mathrm{Ca}$ application makes the middle lamella of fruit cell wall thicker by increased deposition of calcium pectate and so, maintains the firmness 
of fruit (Sudha et al., 2007). The use of wax emulsion has been found to increase the storage life of guava fruits (Kumar et al., 2012). Wax acts as a barrier of free movement of water, air and oxygen.

Covering with additional layer of wax on the fruit surface by use of wax emulsions like waxol has been reported to have beneficial effect in extending shelf life of several fruits. Therefore, it is needful to subject ber fruits to growth regulator, chemical and wax treatments to evaluate their response on biochemical parameters under cold storage.

\section{Materials and Methods}

The research experiment was carried out during Rabi-2020at Horticultural Research Farm and P. G. Laboratory, Department of Horticulture, B. A. College of Agriculture, Anand Agricultural University, Anand. Uniform sized fruits of Gola cultivar were selected at physiological maturity. The fruits were dipped for 5 minutes.

Treated fruits were then placed in CFB boxes then after in cold storage $\left(8^{\circ} \mathrm{C}\right.$ and $\left.85 \% \mathrm{RH}\right)$. The experiment was laid out in Completely Randomized Design with Factorial concept (FCRD) having fourteen treatments combination comprising of $\mathrm{CaCl}_{2}(0.5,1.0$ and $2.0 \%), \mathrm{GA}_{3}(20,40$ and $60 \mathrm{ppm})$, wax $(6 \%)$ and with control (water) and three replications.

Fruits samples were analysed for physiobiochemical changes like physiological loss in weight $(\%)$, spoilage (\%),marketable fruits $(\%)$, firmness $\left(\mathrm{Kgcm}^{-2}\right)$, total soluble solids ( ${ }^{\circ}$ brix), acidity (\%), ascorbic acid (mg/100g pulp), total sugar $(\%)$, reducing sugar $(\%)$ and non reducing sugar $(\%)$. Observations recorded at every five (5) days intervals (i.e., $5^{\text {th }}, 10^{\text {th }}$, $15^{\text {th }}$ and $20^{\text {th }}$ days) up to $20^{\text {th }}$ days during storage.

\section{Results and Discussion}

\section{Physiological parameters}

Physiological loss in weight (PLW) (\%) and Fruit firmness $\left(\mathrm{Kgcm}^{-2}\right)$

PLW of fruits increased significantly with advancement of storage period regardless of post-harvest treatments. At the end of storage, fruits treated in $\mathrm{CaCl}_{2}(2.0 \%)$ with wax coating $(6 \%)$ showed minimum PLW (8.44 $\%)$ as compared to control (water spray and without wax) $(26.84 \%)$. Coating of wax $(6 \%)$ to treated fruit with $\mathrm{CaCl}_{2}(2.0 \%)$ was effective in creating a physical barrier to moisture loss, hence reduced weight loss observed for the treated fruits (1.37 to $8.44 \%$ ) than for non treated fruits (3.2 to $26.84 \%$ ). This is might be due to weight loss of fresh fruits is mainly due to water loss because of transpiration while dry matter is lost by respiration. Hence, the lowest PLW of the fruits could be effect of $\mathrm{CaCl}_{2}$ dipping on respiration, which probably lowered the rate of transpiration, water loss and oxidation reactions and related to modified atmosphere created by wax coating. These results were in accordance with the finding of Seleshi et al., (2019) in nectarine, who observed treating nectarine fruits with $3 \%$ BeesWax with $4.5 \%$ $\mathrm{CaCl}_{2}$ kept the PLW low up to the end of shelf life. The similar result on PLW was reported by Gaikwad et al., (2006) in mango and Dhumal et al., (2008) in aonla. Datain Table (1) revealed that all the treatments exhibited non significant effect for fruit firmness upto $15^{\text {th }}$ day of storage. At the end of storage $\left(20^{\text {th }}\right.$ day) it was highest in treatment $\left(\mathrm{C}_{6} \mathrm{~W}_{1}\right)$ and lowest in control treatment $\left(\mathrm{C}_{7} \mathrm{~W}_{2}\right)$.

\section{Spoilage (\%)}

Data in (Table 1) showed that there was no spoilage in all the treatments up to $5^{\text {th }}$ days of storage. Then after fast spoilage observed in 
all the treatments with advancement of storage regardless of the treatments. The treatment combination of $\mathrm{CaCl}_{2}(2.0 \%)$ with wax coating $(6 \%)$ showed lowest spoilage over control through the storage. This might be due to combined role of $\mathrm{CaCl}_{2}$, which act as a reducer of fruit softening by strengthening of the cell walls and beeswax by covering cuticle and lenticels of the fruits. Hence, reduction of respiration rate and ripening process by the treatments probably minimized the occurrence of fruit spoilage. Seleshi et al., (2019) reported similar finding where nectarine fruits treated either at $3 \%$ BeesWax $+3.0 \% \mathrm{CaCl}_{2}$ or $3 \%$ BeesWax $+4.5 \% \mathrm{CaCl}_{2}$ better reduced the spoilage up to shelf life termination. This might be due to slow release of free water on an effect of reduced metabolism and rate of transpiration in calcium treated fruits. The similar result was reported by Khanvilkar et al., (2018), who reported sapota fruits treated with $\left(\mathrm{CaCl}_{2} 1.0 \%\right)$ recorded lowest spoilage.

The lowest spoilage fruits in the wax coating might be due to inhibition of sporulation and spore germination of rot causing fungus. These results were in accordance with the finding of Jawadagi et al., (2013) who noticed that the application of the wax emulsion $10 \%$ recorded lowest spoilage of in custard apple.

\section{Marketable fruits (\%)}

The maximum marketable fruits were found $(88.66 \%)$ in treatment $\left(\mathrm{C}_{6} \mathrm{~W}_{1}\right)$ up to $15^{\text {th }}$ day of storage (Table 1) and minimum recorded in control treatment $(45.80 \%)$. Then after decline trend observed. Due to the lowest firmness loss, shrivelling, spoilage occurrence and better appearance had delayed metabolic rates resulted in the highest percentage of marketable fruits. Seleshi et al., (2019) who noticed that $3 \%$ Bee Wax $+4.5 \%$ $\mathrm{CaCl}_{2}$ treatment had consistently kept the highest percentage of marketable fruits up to the last date of storage life of nectarine fruits.

\section{Bio-chemical parameters}

\section{Total soluble solids ( $\left.{ }^{0} \mathrm{Brix}\right)$}

TSS content of fruits increased up to $15^{\text {th }}$ days of storage in all the treatments except the control $\left(\mathrm{C}_{7} \mathrm{~W}_{2}\right)$, which recorded increasing TS content only up to $10^{\text {th }}$ days of storage (Table $2)$. However decline trend was observed for TSS in all the treatments at $20^{\text {th }}$ day of storage. Among the different treatments $\mathrm{CaCl}_{2}$ $(2.0 \%)$ with wax coating $(6 \%)$ recorded maximum TSS at the end of storage closely followed by $\mathrm{CaCl}_{2}(1.0 \%)$ with wax coating $(6 \%)$ than other treatments.

This might be due to the calcium helps increase in soluble solids content caused by hydrolysis of polysaccharides like starch, pectin and cellulose substances into simpler substances. The present results is in agreement with Tsomu and Patel (2014), who reported similar finding where sapota fruits treated with $\mathrm{CaCl}_{2} 1.0 \%$ recorded highest TSS.

Bee wax coating delayed degradation process of carbohydrates and reduced transpiration from the fruits. Jakhar and Pathak, 2015 who noticed that treatment of HWT+Wax coating also retained the highest TSS followed by wax coating treatment upto 18 days of storage in mango.

\section{Acidity (\%)}

Data presented in (Table 2) indicated that acidity content was gradually decline in all treatments as storage period progressed. At the end of cold storage, lowest acidity was recorded in $\mathrm{CaCl}_{2}(2.0 \%)$ with wax coating (6 $\%)$, where as highest acidity observed in control (water spray and without wax). This is might be due to slow metabolic rates. Netravati et al., (2018)reported similar finding where custard apple fruits treated wax (1:10) and $\mathrm{CaCl}_{2}(4 \%)$ retained least titrable acidity. 
Table.1 Effect of different levels of post-harvest treatments of chemical and wax on Physiological loss in weight (\%), Spoilage (\%), Marketable fruits (\%)and Firmness $\left(\mathrm{Kgcm}^{-2}\right)$ of berunder cold storage condition cv. Gola

\begin{tabular}{|c|c|c|c|c|c|c|c|c|c|c|c|c|c|c|c|c|}
\hline \multirow[t]{3}{*}{ Treatments } & \multicolumn{4}{|c|}{$\begin{array}{c}\text { Physiological loss in } \\
\text { weight }(\%)\end{array}$} & \multicolumn{4}{|c|}{ Spoilage (\%) } & \multicolumn{4}{|c|}{ Marketable fruits (\%) } & \multicolumn{4}{|c|}{ Firmness $\left(\mathrm{Kgcm}^{-2}\right)$} \\
\hline & \multicolumn{4}{|c|}{ Storage period in days } & \multicolumn{4}{|c|}{ Storage period in days } & \multicolumn{4}{|c|}{ Storage period in day } & \multicolumn{4}{|c|}{ Storage period in days } \\
\hline & $5^{\text {th }}$ & $10^{\text {th }}$ & $5^{\text {th }}$ & $5^{\text {th }}$ & $5^{\text {th }}$ & $10^{\text {th }}$ & $15^{\text {th }}$ & $20^{\text {th }}$ & $5^{\text {th }}$ & $10^{\text {th }}$ & $15^{\text {th }}$ & $20^{\text {th }}$ & $5^{\text {th }}$ & $10^{\text {th }}$ & $15^{\text {th }}$ & $20^{\text {th }}$ \\
\hline $\mathbf{C}_{1} \mathbf{W}_{1}$ & 3.17 & 5.85 & 8.76 & 10.26 & 0 & 10.41 & 35.27 & 46.58 & 100 & 89.59 & 64.72 & 53.42 & 6.79 & 6.54 & 6.00 & 5.90 \\
\hline $\mathbf{C}_{1} \mathbf{W}_{2}$ & 26 & 5.99 & 8.97 & 10.60 & 0 & 15.00 & 39.20 & 58.64 & 100 & 5.00 & & & 6.86 & 6.39 & 5.87 & 5.82 \\
\hline $\mathbf{C}_{2} \mathbf{W}_{1}$ & 2.22 & 5.66 & 7.51 & 9.45 & 0 & 10.00 & 14.33 & 29.33 & 100 & 90.00 & 85.66 & 70.66 & 7.03 & 6.44 & 6.36 & 5.86 \\
\hline $\mathbf{C}_{2} \mathbf{W}_{2}$ & 21 & 6.25 & 8.88 & 10.63 & 0 & 13.00 & 34.13 & 49.62 & 100 & 7.00 & & & 6.8 & 6.36 & & 5.90 \\
\hline $\mathbf{C}_{3} \mathbf{W}_{1}$ & 2.07 & 5.44 & 7.43 & 9.32 & 0 & 8.00 & 15 & 35.37 & 100 & & & & 7.04 & 6.72 & 6.40 & 6.11 \\
\hline $\mathbf{C}_{3} \mathbf{W}_{2}$ & 21 & 5.36 & 8.31 & 10.04 & 0 & 14.20 & 26.33 & 56.60 & 100 & & & & 6.8 & 6.46 & 6.0 & 5.93 \\
\hline $\mathrm{C}_{4} \mathrm{~W}_{1}$ & & 5.26 & 7.66 & 9.27 & 0 & & & & 100 & & & & & & & 6.09 \\
\hline $\mathrm{C}_{4} \mathbf{W}_{2}$ & .32 & 6.50 & 7.32 & 10.23 & 0 & 11.00 & 33.66 & 48.35 & 100 & 89.00 & 66 & 51.65 & 6.67 & 6.48 & 6.27 & 5.23 \\
\hline $\mathrm{C}_{5} \mathrm{~W}_{1}$ & & 4.26 & 6.52 & & 0 & & & & & & & & & & & 6.08 \\
\hline $\mathrm{C}_{5} \mathrm{~W}_{2}$ & .09 & 5.42 & 7.44 & 9.95 & 0 & 13.00 & 31.00 & 46.61 & 100 & 87.00 & 69.00 & 53.39 & 6.95 & 6.67 & 6.49 & 5.30 \\
\hline $\mathrm{C}_{6} \mathrm{~W}_{1}$ & & 4.15 & 6.35 & 8.44 & 0 & 3.66 & & 26.21 & 100 & 96.33 & 88.66 & 73.78 & 7.12 & 6.83 & 6.64 & 6.33 \\
\hline $\mathrm{C}_{6} \mathrm{~W}_{2}$ & 2.05 & 5.30 & 7.29 & 9.85 & 0 & 10.66 & 29.33 & 35.94 & 100 & 89.33 & 70.66 & 64.05 & 6.99 & 6.79 & 6.39 & 5.95 \\
\hline $\mathbf{C}_{7} \mathbf{W}_{1}$ & 2.50 & 6.86 & 9.67 & 10.58 & 0 & 17.00 & 34.48 & 51.99 & 100 & 83.00 & 65.51 & 48.00 & 6.56 & 6.38 & 6.13 & 5.46 \\
\hline $\mathbf{C}_{7} \mathbf{W}_{2}$ & 3.20 & 6.75 & 10.52 & 26.84 & 0 & 25.97 & 54.19 & 69.37 & 100 & 74.02 & 45.80 & 30.62 & 6.26 & 6.17 & 5.68 & 4.96 \\
\hline S.Em. \pm & 0.08 & 0.17 & 0.15 & 0.24 & - & 0.20 & 0.88 & 1.70 & - & 0.54 & 0.88 & 1.70 & 0.11 & 0.10 & 0.12 & 0.10 \\
\hline $\begin{array}{c}\text { C.D. at } 5 \\
\%\end{array}$ & 0.25 & 0.51 & 0.44 & 0.71 & - & 0.60 & 2.57 & 4.94 & - & 1.59 & 2.57 & 4.94 & $\mathrm{NS}$ & NS & NS & 0.30 \\
\hline C.V. \% & 6.40 & 5.48 & 3.32 & 3.87 & - & 8.08 & 5.55 & 6.69 & - & 1.08 & 2.13 & 5.29 & 2.45 & 2.23 & 2.73 & 3.11 \\
\hline
\end{tabular}

$\mathrm{C}_{1^{-}} \mathrm{GA}_{3} 20 \mathrm{ppm}, \mathrm{C}_{2}-\mathrm{GA}_{3} 40 \mathrm{ppm}, \mathrm{C}_{3^{-}} \mathrm{GA}_{3} 60 \mathrm{ppm}, \mathrm{C}_{4^{-}} \mathrm{CaCl}_{2} 0.5 \%, \mathrm{C}_{5^{-}} \mathrm{CaCl}_{2} 1.0 \%, \mathrm{C}_{6^{-}}-\mathrm{CaCl}_{2} 2.0 \%$

$\mathrm{W}_{1}$ - With $6 \%$ wax coating and $\mathrm{W}_{2}$ - Without wax coating 
Table.2 Effect of different levels of post-harvest treatments of chemical and wax on Total Soluble Solids ( ${ }^{\circ}$ Brix $)$, Acidity $(\%)$ and Ascorbic acid (mg/100 g pulp) of ber under cold storage condition cv. Gola

\begin{tabular}{|c|c|c|c|c|c|c|c|c|c|c|c|c|}
\hline \multirow[t]{3}{*}{ Treatments } & \multicolumn{4}{|c|}{ Total Soluble Solids ( ${ }^{\circ}$ Brix) } & \multicolumn{4}{|c|}{ Acidity (\%) } & \multirow{2}{*}{\multicolumn{4}{|c|}{$\begin{array}{c}\text { Ascorbic acid (mg/100 g pulp) } \\
\text { Storage period in days }\end{array}$}} \\
\hline & \multicolumn{4}{|c|}{ Storage period in days } & \multicolumn{4}{|c|}{ Storage period in days } & & & & \\
\hline & $5^{\text {th }}$ & $10^{\text {th }}$ & $15^{\text {th }}$ & $20^{\text {th }}$ & $5^{\text {th }}$ & $10^{\text {th }}$ & $15^{\text {th }}$ & $20^{\text {th }}$ & $5^{\text {th }}$ & $10^{\text {th }}$ & $15^{\text {th }}$ & $20^{\text {th }}$ \\
\hline $\mathbf{C}_{1} \mathbf{W}_{1}$ & 12.24 & 12.77 & 12.80 & 11.94 & 0.213 & 0.197 & 0.182 & 0.164 & 76.79 & 73.32 & 69.16 & 58.19 \\
\hline $\mathbf{C}_{1} \mathbf{W}_{2}$ & 11.24 & 12.64 & 12.85 & 11.44 & 0.266 & 0.234 & 0.190 & 0.181 & 73.54 & 70.40 & 67.97 & 54.57 \\
\hline $\mathrm{C}_{2} \mathrm{~W}_{1}$ & 11.53 & 12.43 & 13.18 & 12.50 & 0.210 & 0.200 & 0.180 & 0.179 & 81.41 & 81.08 & 75.86 & 61.17 \\
\hline $\mathbf{C}_{2} \mathbf{W}_{2}$ & 11.47 & 12.96 & 13.13 & 11.14 & 0.268 & 0.253 & 0.240 & 0.225 & 74.96 & 74.18 & 71.48 & 57.79 \\
\hline $\mathrm{C}_{3} \mathbf{W}_{1}$ & 13.22 & 13.77 & 13.92 & 12.56 & 0.224 & 0.192 & 0.183 & 0.173 & 76.72 & 79.62 & 75.79 & 62.83 \\
\hline $\mathbf{C}_{3} \mathbf{W}_{2}$ & 11.22 & 12.96 & 13.08 & 11.36 & 0.272 & 0.267 & 0.263 & 0.255 & 78.80 & 75.76 & 70.81 & 60.46 \\
\hline $\mathrm{C}_{4} \mathrm{~W}_{1}$ & 12.41 & 13.72 & 14.06 & 12.30 & 0.204 & 0.183 & 0.178 & 0.167 & 82.10 & 79.90 & 76.87 & 63.41 \\
\hline $\mathrm{C}_{4} \mathbf{W}_{2}$ & 12.33 & 13.37 & 13.55 & 11.18 & 0.267 & 0.264 & 0.195 & 0.188 & 73.95 & 73.08 & 68.00 & 63.14 \\
\hline $\mathrm{C}_{5} \mathrm{~W}_{1}$ & 13.42 & 14.17 & 14.24 & 13.41 & 0.204 & 0.187 & 0.174 & 0.159 & 84.93 & 77.70 & 76.61 & 64.28 \\
\hline $\mathrm{C}_{5} \mathrm{~W}_{2}$ & 12.57 & 13.20 & 13.26 & 12.39 & 0.252 & 0.240 & 0.235 & 0.211 & 71.95 & 69.27 & 64.12 & 61.79 \\
\hline $\mathrm{C}_{6} \mathrm{~W}_{1}$ & 13.65 & 14.21 & 14.32 & 13.75 & 0.201 & 0.178 & 0.166 & 0.145 & 85.08 & 81.65 & 78.02 & 65.58 \\
\hline $\mathrm{C}_{6} \mathrm{~W}_{2}$ & 12.80 & 13.27 & 13.33 & 11.78 & 0.285 & 0.268 & 0.260 & 0.256 & 72.07 & 78.51 & 74.41 & 61.43 \\
\hline $\mathbf{C}_{7} \mathbf{W}_{1}$ & 12.22 & 12.65 & 12.82 & 11.26 & 0.217 & 0.201 & 0.185 & 0.168 & 71.78 & 68.17 & 63.45 & 56.94 \\
\hline $\mathbf{C}_{7} \mathbf{W}_{2}$ & 11.06 & 11.50 & 11.13 & 10.10 & 0.274 & 0.269 & 0.251 & 0.250 & 70.55 & 65.67 & 59.14 & 48.19 \\
\hline S.Em. \pm & 0.27 & 0.11 & 0.08 & 0.18 & 0.007 & 0.005 & 0.004 & 0.003 & 0.70 & 0.77 & 0.62 & 0.46 \\
\hline C.D. at $5 \%$ & 0.78 & 0.34 & 0.25 & 0.54 & NS & 0.014 & 0.010 & 0.009 & 2.05 & NS & 1.82 & 1.33 \\
\hline C.V. \% & 3.82 & 1.56 & 1.12 & 2.72 & 5.150 & 3.636 & 3.040 & 2.647 & 1.60 & 2.52 & 1.54 & 1.33 \\
\hline
\end{tabular}

$\mathrm{C}_{1^{-}} \mathrm{GA}_{3} 20 \mathrm{ppm}, \mathrm{C}_{2}-\mathrm{GA}_{3} 40 \mathrm{ppm}, \mathrm{C}_{3^{-}} \mathrm{GA}_{3} 60 \mathrm{ppm}, \mathrm{C}_{4^{-}} \mathrm{CaCl}_{2} 0.5 \%, \mathrm{C}_{5^{-}} \mathrm{CaCl}_{2} 1.0 \%, \mathrm{C}_{6^{-}} \mathrm{CaCl}_{2} 2.0 \%, \mathrm{~W}_{1^{-}}$With $6 \%$ wax coating and $\mathrm{W}_{2^{-}}$Without wax coating 
Table.3 Effect of different levels of post-harvest treatments of chemical and wax on Total sugar (\%), Reducing sugar (\%) and Nonreducing sugar $(\%)$ of ber under cold storage condition cv. Gola

\begin{tabular}{|c|c|c|c|c|c|c|c|c|c|c|c|c|}
\hline \multirow[t]{3}{*}{ Treatments } & \multicolumn{4}{|c|}{ Total sugar (\%) } & \multicolumn{4}{|c|}{ Reducing sugar (\%) } & \multicolumn{4}{|c|}{ Non-reducing sugar (\%) } \\
\hline & \multicolumn{4}{|c|}{ Storage period in days } & \multicolumn{4}{|c|}{ Storage period in days } & \multicolumn{4}{|c|}{ Storage period in day } \\
\hline & $5^{\text {th }}$ & $10^{\text {th }}$ & $15^{\text {th }}$ & $20^{\text {th }}$ & $5^{\text {th }}$ & $10^{\text {th }}$ & $15^{\text {th }}$ & $20^{\text {th }}$ & $5^{\text {th }}$ & $10^{\text {th }}$ & $15^{\text {th }}$ & $20^{\text {th }}$ \\
\hline $\mathbf{C}_{1} \mathbf{W}_{1}$ & 8.55 & 9.34 & 8.86 & 8.53 & 4.36 & 4.65 & 4.01 & 4.27 & 4.52 & 4.68 & 4.85 & 4.25 \\
\hline $\mathbf{C}_{1} \mathbf{W}_{2}$ & 8.70 & 9.24 & 8.95 & 8.80 & 4.41 & 4.62 & 4.72 & 4.15 & 4.28 & 4.62 & 4.23 & 4.65 \\
\hline $\mathbf{C}_{2} \mathbf{W}_{1}$ & 8.59 & 9.76 & 9.59 & 9.42 & 4.72 & 4.81 & 4.79 & 4.40 & 3.87 & 4.94 & 4.8 & 5.02 \\
\hline $\mathbf{C}_{2} \mathbf{W}_{2}$ & 8.54 & 8.95 & 8.87 & 8.08 & 4.42 & 4.36 & 4.74 & 3.94 & 4.11 & 4.58 & 4.12 & 4.14 \\
\hline $\mathbf{C}_{3} \mathbf{W}_{1}$ & 8.51 & 9.66 & 10.11 & 9.37 & 4.54 & 4.80 & 5.52 & 4.30 & 3.97 & 4.85 & 4.59 & 5.07 \\
\hline $\mathbf{C}_{3} \mathbf{W}_{2}$ & 8.43 & 9.71 & 8.84 & 8.27 & 4.26 & 4.41 & 5.06 & 4.36 & 4.16 & 5.29 & 3.78 & 3.90 \\
\hline $\mathrm{C}_{4} \mathrm{~W}_{1}$ & 8.96 & 10.09 & 10.34 & 9.02 & 5.53 & 5.02 & 5.31 & 3.66 & 3.43 & 5.07 & 5.03 & 5.36 \\
\hline $\mathrm{C}_{4} \mathrm{~W}_{2}$ & 8.35 & 8.61 & 9.66 & 9.32 & 4.24 & 4.36 & 5.55 & 4.70 & 4.11 & 4.25 & 4.11 & 4.61 \\
\hline $\mathrm{C}_{5} \mathrm{~W}_{1}$ & 9.42 & 10.15 & 10.56 & 10.02 & 5.09 & 5.20 & 5.50 & 4.23 & 4.33 & 4.95 & 5.06 & 5.78 \\
\hline $\mathrm{C}_{5} \mathrm{~W}_{2}$ & 8.40 & 9.67 & 9.71 & 9.12 & 4.46 & 4.55 & 4.79 & 4.22 & 3.94 & 5.11 & 4.91 & 4.90 \\
\hline $\mathrm{C}_{6} \mathrm{~W}_{1}$ & 9.85 & 10.34 & 11.16 & 10.15 & 5.31 & 4.81 & 5.81 & 4.94 & 4.54 & 5.52 & 5.35 & 5.21 \\
\hline $\mathrm{C}_{6} \mathrm{~W}_{2}$ & 8.85 & 9.47 & 9.78 & 9.59 & 4.50 & 4.62 & 4.71 & 4.46 & 4.35 & 4.84 & 5.07 & 5.12 \\
\hline $\mathrm{C}_{7} \mathbf{W}_{1}$ & 8.33 & 8.80 & 9.11 & 8.05 & 4.27 & 4.39 & 4.03 & 3.62 & 4.05 & 4.41 & 5.08 & 4.43 \\
\hline $\mathbf{C}_{7} \mathbf{W}_{2}$ & 7.47 & 7.74 & 7.51 & 6.74 & 3.42 & 3.55 & 3.83 & 3.40 & 4.05 & 4.19 & 3.68 & 3.34 \\
\hline S.Em. \pm & 0.21 & 0.23 & 0.24 & 0.30 & 0.19 & 0.11 & 0.22 & 0.19 & 0.25 & 0.27 & 0.25 & 0.23 \\
\hline C.D. at $5 \%$ & 0.63 & 0.66 & 0.72 & 0.87 & 0.55 & 0.32 & 0.64 & 0.56 & NS & NS & NS & 0.67 \\
\hline C.V. \% & 4.39 & 4.24 & 4.54 & 5.88 & 7.24 & 4.29 & 7.90 & 8.11 & 8.72 & 7.98 & 7.94 & 8.56 \\
\hline
\end{tabular}

$\mathrm{C}_{1^{-}} \mathrm{GA}_{3} 20 \mathrm{ppm}, \mathrm{C}_{2^{-}} \mathrm{GA}_{3} 40 \mathrm{ppm}, \mathrm{C}_{3^{-}} \mathrm{GA}_{3} 60 \mathrm{ppm}, \mathrm{C}_{4^{-}} \mathrm{CaCl}_{2} 0.5 \%, \mathrm{C}_{5^{-}} \mathrm{CaCl}_{2} 1.0 \%, \mathrm{C}_{6^{-}} \mathrm{CaCl}_{2} 2.0 \%, \mathrm{~W}_{1^{-}}$With 6 \% wax coating and $\mathrm{W}_{2^{-}}$Without wax coating 
The reduction in acidity during storage might be associated with the conversion of organic acid into sugar and their derivatives or their utilization in respiration. Similar result was also reported by Shrinu et al., (2017) who reported papaya fruits treated with $\mathrm{CaCl}_{2} 1.0$ $\%$ recorded lowest acidity. This might be due to conversions of acids into salts and sugar by the enzymes, particularly invertase. These are in conformity with reported by Shahid and Abbashi (2011) who noticed that the application of the bee wax $5 \%$ recorded lowest acidity in sweet orange.

\section{Ascorbic acid(mg/100g pulp)}

Data pertaining to ascorbic acid in the fruit are presented in Table 2. Ascorbic acid content in control treatment $\mathrm{C}_{7} \mathrm{~W}_{2}$ (water spray without wax coating) decreased significantly during storage and this decline was also observed in $\mathrm{CaCl}_{2}(2.0 \%)$ with wax coating $(6 \%)$ treated fruits. No significance difference in ascorbic acid content was observed at $10^{\text {th }}$ days of storage among the treatments. However, with further progression of storage period, the ascorbic acid content was gradually reduced, though $\mathrm{CaCl}_{2}(2.0 \%)$ with wax coating $(6 \%)$ treated fruit still maintained higher values of ascorbic acid than the control and other treatments.

These results were in accordance with the finding of Seleshi et al., (2019) in nectarine, who observed higher ascorbic acid content of nectarine fruits was maintained with $\mathrm{CaCl}_{2}$ dipping and beeswax coating, particularly $3 \%$ Bee $\mathrm{Wax}+4.5 \% \mathrm{CaCl}_{2}$ treated fruits.

The increase in ascorbic acid content might be due to continued activity of enzymes responsible for synthesis of ascorbic acid. The similar results on ascorbic acid reported by Gupta et al., (1987) who reported ber fruits treated with $\mathrm{CaCl}_{2} 2.0 \%$ recorded higher ascorbic acid. This might be due to the degradation of ascorbic acid in the fruits. These results were in accordance with the findings of Singh et al., (2012) who noticed that the application of Bavistin $500 \mathrm{mg} / \mathrm{l}+$ Wax emulsion $6 \%$ recorded higher ascorbic acid in mango.

\section{Total sugar (\%), Reducing sugar (\%) and Non reducing sugar $(\%)$}

The effect of treatments on total sugar and reducing sugar was significant. The total sugar showed an increasing trend up to $10^{\text {th }}$ days of storage in all the treatments however decline trend was observed at $15^{\text {th }}$ and $20^{\text {th }}$ days of storage. The highest TS was recorded in $\mathrm{C}_{6} \mathrm{~W}_{1}$ throughout storage period than control $\mathrm{C}_{7} \mathrm{~W}_{2}$. Reducing sugar had non consistent trend for reducing sugar in all the treatments throughout the storage. However maximum reducing sugar was recorded in $\mathrm{C}_{6} \mathrm{~W}_{1}$ at the end of storage $\left(20^{\text {th }}\right.$ day) than control $\mathrm{C}_{7} \mathrm{~W}_{2}$. Non reducing sugar was found non significant at $5^{\text {th }}, 10^{\text {th }}$ and $15^{\text {th }}$ day of storage, however, significant at $20^{\text {th }}$ day of storage. This might be due to hydrolysis of starch and accumulation of sugars. These results were in accordance with the findings of Tsomu and Patel (2014) in sapota fruits treated $\mathrm{CaCl}_{2} 1.0$ $\%$ highest total sugar. The slower rate of increase in sugars content in wax coated fruits might be due to the delayed degradation processes and less conversion of starch in to simple sugars. Jakhar and Pathak, 2015 who noticed that treatment of HWT+Wax coating also retained the highest total sugar followed by wax coating treatment upto 18 days of storage in mango. The similar result was reported by Ghadage(2011) in papaya.

On the basis of present findings, the result revealed that ber fruits treated with $\mathrm{CaCl}_{2} 2.0$ $\%$ (dipping 5 minutes) coated with wax $(6 \%)$ has prolonging shelf life up to 15 day of storage with improving fruit quality under cold storage $\left(8{ }^{0} \mathrm{C}\right.$ and $\left.85 \% \mathrm{RH}\right)$. 


\section{References}

Dhumal, S. S., Karale, A. R., Garande, V. K., Patil, B. T., Masalkar, S. D. \& Kshirsagar, D. B. (2008). Shelf life of aonla fruits: Influenced by post-harvest treatments and packaging materials. Indian J. Agric. Res., 42 (3), 189-194.

Gaikwad, R. S., Masalkar, S. D. \& Dhemre, J. K. (2006). Effect of post-harvest treatments on organoleptic evaluation and quality of Alphoso mango fruits. Agric. Sci. Digest., 26 (1), 42-44.

Ghadage, V. R. (2011). Effect of post-harvest application of calcium chloride and wax emulsion on ripening and storage behaviour of papaya cv. Taiwan Red Lady. (Published M. Sc. thesis). Navsari Agricultural University, Navsari.

Gupta, O. P., Siddiqui S., and Chauhan, K. S. (1987). Evaluation of various calcium compounds for increasing the shelf life of ber (Ziziphus mauritiana Lamk.) fruits. Indian. J. Agric. Res., 21 (2), 65-70.

Jakhar, M. S. \& Pathak, S. (2015). Influence of hot water treatment and wax coating on quality and storage life of mango (Mangifera indica L.) fruits $\mathrm{cv}$. Amrapali under ambient condition. An International Journal of Environmental Sciences., 9 (3 \&4), 745-750.

Jawadagi, R. S., Patil, D. R., Peerajade, D. A., Shreedhar, D. and Achari, R. (2013). Studies on effect of post-harvest treatments on quality and shelf life of custard apple (Annonasquamosa L.) cv. Balanagar. The Asian Journal of Horticulture., 8 (2), 494-497.

Khanvilkar, M. H., Kaushik, R. A., Pawar, C. D., Pethe, U. B., Talha, P. M., Saroli, D. K., Upadhyay, B. \& Mahawer, L. N. (2018). Response of post-harvest treatments of various chemical and plant growth regulators on physical parameters of sapota fruits $\mathrm{cv}$. Kalipatti. International Journal of Chemical Studies., 6 (2), 3429-3431.

Kumar, P. N., Vikram, B. \& Prasad, V. M. (2012). Effect of chemicals on shelf life and quality of guava (Psidium guajava) fruits cv. Apple Colour. HortFlora Research Spectrum., 1 (3), 220-224.

Netravati, Suresh, G. J. \& Jagadeesh, S. L. (2018). Calcium chloride and wax influences the post-harvest behaviour of custard apple fruits. Journal of Pharmacognosy and Phytochemistry., 7 (2), 79-84.

Seleshi, G., Woldetsadik, K. \& Azene, M. (2019). Effect of calcium chloride dipping and beeswax coating on the shelf life and quality of nectarine (Prunuspersica (L.) Batsch var. nucipersica) fruits. Agriculture and Food Sciences Research, 6 (1), 71-78.

Shahid, M. N. \& Abbasi, N. A. (2011). Effect of bee wax coatings on physiological changes in fruits of sweet orange cv. Blood Orange. Sarhad J. Agric., 27 (3).

Singh, A. K., Singh, C. P., Kushwaha, P. S. \& Chakraborty, B. (2012). Efficacy of post-harvest treatments on fruit marketability and physico-chemical characteristics of Dashehari mango. Progressive Horticulture., 44 (2), 215219.

Srinu, B., Rao, Manohar A., Joshi, Veena K., Reddy, Narender $\mathrm{S}$ and Sharma, Harish Kumar. (2017). Effect of different post -harvest treatments on quality and shelf life of papaya. Journal of Pharmacognosy and Phytochemistry., 6 (5), 1788-1792.

Sudha, R., Amutha, R., Muthulaksmi, S., Baby Rani, W., Indira, K., and Mareeswari, P. (2007). Influence of Pre and Post-harvest Chemical 
Treatments on Physical Characteristics of Sapota (Achras sapota L.) Var. PKM-1. Research Journal of Agriculture and Biological Sciences., 3 (5), 450-452.

Tsomu, T. \& and Patel, H. C. (2015). Effect of post-harvest treatments of chemical and plant growth regulators on biochemical characteristics of sapota fruit cv. Kalipatti. An International Quarterly Journal of Life Sciences., 10 (1), 33-36.

\section{How to cite this article:}

Patel, N. A., B. H. Panchal and Rathod, M. B. 2021. Effect of Post Harvest Treatments on Storage Quality of Ber (Ziziphus mauritiana Lamk.) under Cold Storage Condition cv. Gola. Int.J.Curr.Microbiol.App.Sci. 10(06): 158-166. doi: https://doi.org/10.20546/ijcmas.2021.1006.017 